\title{
Comparative phytochemical, antioxidant, and antibacterial study of different parts of Doigota plants (Bixa orellana L.)
}

Sium Ahmed ${ }^{1}$, Bilkis Mehrin Moni ${ }^{1}$, Shawon Ahmed', Donald James Gomes ${ }^{2}$ and Abdullah Mohammad Shohael ${ }^{*}$ (i)

\begin{abstract}
Background: Bixa orellana $\mathrm{L}$. is a plant native to Brazil but grows in other parts of the world including Bangladesh. This plant has been used for many years by indigenous people around the globe for a variety of applications. In Bangladesh, it is known as Doigota and the plant is underutilized and reported endangered. The present study aimed to perform comparative profiling where aqueous, ethanolic, and methanolic extracts of the seed, branch, and leaf of $B$. orellana plants were investigated for in vitro phytochemicals, antioxidant, and antibacterial activities.

Results: Phytochemical screening indicated the presence of nine different phytochemicals in varying degrees, which suggests the chemical diversity of this plant. Quantification of phenolics, flavonoids, and tannins was performed where leaf extracts contained significantly higher quantities of these phytochemicals than extracts from seed and branch. The highest phenolics $(186.02 \mathrm{mg} / \mathrm{g})$ were found in the methanolic extract of the leaf, whereas the highest flavonoids $(61.01 \mathrm{mg} / \mathrm{g})$ and tannins $(36.74 \mathrm{mg} / \mathrm{g})$ were found in aqueous extract of the leaf. Antioxidant activity has been evaluated by DPPH scavenging assay where the aqueous extract of leaf showed $93.62 \%$ scavenging activity at $800 \mathrm{\mu g} / \mathrm{mL}$ extract concentration. Although the extracts prevented the growth of both Grampositive and Gram-negative bacteria, the antibacterial activity (zone of inhibition) of aqueous and methanolic extracts of the leaves were higher than those of the seed and branch extracts against Gram-negative (Escherichia coli) and Gram-positive (Bacillus subtilis) bacteria, respectively.
\end{abstract}

Conclusions: We found that $B$. orellana leaf extracts possess the highest antibacterial activities. The extracts had significant antioxidant and free radical-scavenging activities. The antioxidant and antibacterial activities could be attributed to high flavonoid and phenolic contents. These results suggest that the extracts of $B$. orellana possess bioactive compounds that could be used for different purposes such as source of new antibiotics or alternative natural preservatives in food matrices due to mainly their antioxidant and antibacterial activities.

Keywords: Antibiotics, Antioxidants, Bioactive compounds, Doigota, Phytochemicals

\footnotetext{
* Correspondence: amshohael@juniv.edu

'Cell Genetics and Plant Biotechnology Laboratory, Department of

Biotechnology and Genetic Engineering, Jahangirnagar University, Savar,

Dhaka 1342, Bangladesh

Full list of author information is available at the end of the article
}

\section{Springer Open}

(c) The Author(s). 2020 Open Access This article is licensed under a Creative Commons Attribution 4.0 International License, which permits use, sharing, adaptation, distribution and reproduction in any medium or format, as long as you give appropriate credit to the original author(s) and the source, provide a link to the Creative Commons licence, and indicate if changes were made. The images or other third party material in this article are included in the article's Creative Commons licence, unless indicated otherwise in a credit line to the material. If material is not included in the article's Creative Commons licence and your intended use is not permitted by statutory regulation or exceeds the permitted use, you will need to obtain permission directly from the copyright holder. To view a copy of this licence, visit http://creativecommons.org/licenses/by/4.0/. 


\section{Background}

Bixa orellana L., belonging to the family of Bixaceae, known as the annatto, achiote, or lipstick tree, is a small shrubby tree native of Central and Southern America (Giorgi et al. 2013). It is known as Doigota in Bengali and reported endangered (Rahman and Fakir 2015). It is found mainly in the Brazilian forest ecosystems with humid tropical conditions and now being cultivated in tropical areas throughout the world (Mello and Lima 1990). It has achieved economic importance because it contains natural reddish-orange pigment in its seeds composed primarily of the carotenoids bixin and norbixin, for which it is also referred to as annatto (Stohs 2014). It has been traditionally used by the people as a dye to paint hair and body as insect repellant or protectant from sunburn (Patani et al. 2013). Food industries use $B$. orellana as a colorant in butter, margarine, cheese, biscuits, dairy products, and chocolates (Shilpi et al. 2006). It is also implemented in textile industries for dyeing of jute, wool, cotton, and silk. In the global market, it has a preference next to saffron as a natural food grade colorant due to its non-toxicity as well as its tendency to preserve natural food flavor (Smith 2006). It has also traditional value in folklore medicine as it is consumed as a digestive aid and as a medication to control stomach disorders. Particularly, leaf extracts have been used for many years to treat headache, dysentery, fever, various microbial diseases, heartburn, and indigestion (Stohs 2014). The seeds are used to treat fever, skin diseases, and gonorrhea. The seed-derived oil is used to cure leprosy, and the decoction is used to treat jaundice (Tamil Selvi et al. 2011; Yusuf et al. 1994).

Plants have been a rich source of effective and safe medicine. About $80 \%$ of the world's population is still dependent on traditional medicines. Different phytochemicals are present in the medicinal plants which are the key source of new pharmaceuticals and healthcare products (Tiwari 2008). The history of plants used for medicinal purposes is probably as old as human history. Plants have been subjected to extensive research because they contain secondary metabolites (bioactive components) that have beneficial therapeutic effects and various health-promoting activities. It has been reported that bioactive compounds such as phenolics, flavonoids, tannins, and carotenoids exhibit antioxidant properties (Rincón et al. 2014). In recent years, natural resources have been widely explored for the presence of antioxidants and efforts have been made to identify active antioxidant compounds from natural sources. Free radical scavenging antioxidants are important because they prevent various kinds of diseases and disorders (Ksouri et al. 2009).

Antibiotics are commonly used to treat infectious diseases caused by bacteria. There are various antibiotics available in the markets, which are being used against different pathogenic microorganisms. However, antibiotic resistance led to the emergence of multidrug-resistant bacteria which has become a major concern for public health. This phenomenon gives rise to the concept of using naturally derived compounds for their potential application to control pathogenic microorganisms. Natural compounds may offer a new source of antibiotics more effective than synthetic antibiotics. Regarding this issue, over the last few years, a good number of studies have been conducted worldwide. Previously, three studies involving B. orellana were performed in Bangladesh so far. In the light of previous findings, we designed an elaborate and comparative approach to analyze three different parts (seed, branch, and leaf) of B. orellana, which were extracted with three different solvents (water, ethanol, and methanol). The analysis covered preliminary phytochemical screening, quantitative estimation of phenols, flavonoids, and tannins; antioxidant activity by 2,2-diphenyl-1picrylhydrazyl (DPPH) scavenging assay; and antibacterial analysis using both Gram-negative (Escherichia coli) and Gram-positive (Bacillus subtilis) bacteria. The study was mainly aimed to explore the comparative phytochemical profile and the bioactivity and also the consistency with previous findings.

\section{Materials and methods}

\section{Chemicals and reagents}

All chemicals and reagents used in this study were of analytical grade. Aluminum chloride, (+)-catechin, potassium iodide, DPPH (2,2-diphenyl-1-picrylhydrazyl), and gallic acid were purchased from Sigma Aldrich, USA. Glacial acetic acid was purchased from Scharlau, Spain. Tannic acid was purchased from Loba Chemie, India. Ethanol, methanol, Fehling $\mathrm{A}$ and $\mathrm{B}$, sodium hydroxide, and sodium nitrite were bought from Merck, Germany. Folin-Ciocalteu reagent was purchased from SRL, India. Sodium carbonate, chloroform, and iodine were bought from Alfa Aesar, UK. Hexane and ethyl acetate were bought from Daejung Chemicals and Duksun Pure Chemicals, South Korea, respectively.

\section{Study location and plant materials}

The experiments were conducted at the Cell Genetics and Plant Biotechnology Laboratory, Department of Biotechnology and Genetic Engineering, Jahangirnagar University, Dhaka-1342, Bangladesh (23 $53^{\prime} 14^{\prime \prime} \mathrm{N} 90^{\circ} 15^{\prime}$ $\left.56^{\prime \prime} \mathrm{E}\right)$. Initially, the seeds of Doigota (B. orellana) were collected from some cultivated plants in a garden located at Hemayetpur, Dhaka, Bangladesh, during November 2016. The seeds were germinated, and plants were cultivated in the laboratory garden with appropriate conditions and care during January 2017. Seeds, branches, and leaves were collected during March 2019 
from these 2 years old cultivated plants and used as the experimental materials in this study.

\section{Preparation of extracts}

The plant materials (seed, branch cutting, and leaf) were sun dried for 7 days and then dried in a hot air oven (JSR, Korea) at $50^{\circ} \mathrm{C}$ for 7 days. The dried plant materials were powdered in a mechanical grinder. In the extraction process, distilled water, $70 \%$ ethanol, and $70 \%$ methanol were used as solvents. The powdered materials $(10 \mathrm{~g})$ were taken in conical flasks with $70 \%$ ethanol, $70 \%$ methanol, and distilled water and kept in an orbital shaker for 3 days at room temperature. The extracts were filtered through Whatman No. 1 filter paper, and the filtrates were concentrated using a rotary evaporator at $45^{\circ} \mathrm{C}$. Finally, stock solutions of extracts $(10 \mathrm{mg} / \mathrm{mL})$ were prepared using $0.1 \mathrm{~N} \mathrm{NaCl}$. For qualitative screening and quantitative determination of phytochemicals, the stock extracts were diluted to the concentration of 1 $\mathrm{mg} / \mathrm{mL}$

\section{Qualitative screening of phytochemicals}

The freshly prepared crude extracts were qualitatively tested for the presence of secondary metabolites such as carbohydrates, alkaloids, glycosides, coumarins, tannins, phenols, flavonoids, saponins, and proteins by following the methods described in our previous literature (Ahmed et al. 2018).

\section{Carbohydrates}

One milliliter of different extracts was taken into test tubes to which equal volume of Fehling's A and Fehling's $\mathrm{B}$ were added. The tubes were heated at $65^{\circ} \mathrm{C}$ in a water bath for $10-15 \mathrm{~min}$. Redbrick precipitate indicated the presence of carbohydrates (Ahmed et al. 2018).

\section{Alkaloids}

One milliliter of different extracts was taken into test tubes, and 4-6 drops of Wagner's reagent [1.27 g of iodine and $2 \mathrm{~g}$ of potassium iodide in $100 \mathrm{~mL}$ of water] was added. The radish brown precipitate indicated the presence of alkaloids (Rizk 1982).

\section{Glycosides}

One milliliter of different extracts was mixed with $1 \mathrm{~mL}$ of glacial acetic acid in test tubes. Then, 5-6 drops of $1 \%$ ferric chloride solution were added. Brown color ring produced at the top indicated the presence of glycoside (Peash et al. 2017).

\section{Coumarins}

One milliliter of the extract was added with $1.5 \mathrm{~mL}$ of $10 \% \mathrm{NaOH}$. The chemical reaction produced yellow color and indicated the presence of coumarin (Ugochukwu et al. 2013).

\section{Tannins}

One milliliter of extracts was mixed with $1 \mathrm{~mL}$ of distilled water, and then, 4-5 drops of $1 \%$ ferric chloride were added. Blue and the greenish-black color indicated the presence of gallic tannin and cathecholic tannin respectively (Peash et al. 2017).

\section{Phenols}

One milliliter of ethanol was added to $1 \mathrm{~mL}$ of extracts. Then, 6-7 drops of $1 \%$ ferric chloride solution were added to each tube. Formation of the green or blue or purple color indicated the presence of phenol (Soloway and Wilen 1952).

\section{Flavonoids}

Three to four drops of $20 \% \mathrm{NaOH}$ solution were added to $2 \mathrm{~mL}$ of extracts. The intense yellow color formed and become colorless when 4-5 drops of dilute $\mathrm{HCl}$ was added. This indicated the presence of flavonoids (Ugochukwu et al. 2013).

\section{Saponins}

Two milliliters of distilled water was added to $1 \mathrm{~mL}$ of extracts and shaken for $5 \mathrm{~min}$. The presence of $1-\mathrm{cm}$ thick foam for $10 \mathrm{~min}$ indicated the presence of saponin (Kumar et al. 2009).

\section{Proteins}

One milliliter of the extract was treated with few drops of concentrated $\mathrm{HNO}_{3}$. The formation of yellow color indicated the presence of proteins (Yadav et al. 2017).

\section{Quantitative determination of phytochemicals Determination of total phenolic content}

The total phenolic content of the extracts was estimated according to the method described previously (Shohael et al. 2006a). $0.1 \mathrm{~mL}$ aliquots of extracts and standards of different concentrations were mixed with $2.5 \mathrm{~mL}$ deionized water followed by the addition of $0.1 \mathrm{~mL}(2 \mathrm{~N})$ Folin-Ciocalteu reagent. They were mixed well and allowed to stand for $6 \mathrm{~min}$ before $0.5 \mathrm{~mL}$ of a $20 \%$ sodium carbonate solution was added. The color developed after $30 \mathrm{~min}$ at room temperature. The absorbance was measured at $760 \mathrm{~nm}$ in a UV-visible spectrophotometer (T60 UV-Visible Spectrophotometer, PG Instruments Ltd., UK). The concentration of total phenol was determined using gallic acid as standard. Total phenolic content was expressed as milligrams of gallic acid equivalent (mg GAE)/g of extract. 


\section{Determination of total flavonoid content}

Total flavonoid content was determined following the method described previously (Shohael et al. 2006b). Briefly, $0.25 \mathrm{~mL}$ of extracts or (+)-catechin standard solution was mixed with $1.25 \mathrm{~mL}$ of distilled water, followed by the addition of $0.75 \mathrm{~mL}$ of a $5 \%$ sodium nitrite solution. After $6 \mathrm{~min}, 0.15 \mathrm{~mL}$ of a $10 \%$ aluminum chloride solution was added, and the mixture was allowed to stand for a further $5 \mathrm{~min}$ and then $0.5 \mathrm{~mL}$ of $1 \mathrm{M}$ sodium hydroxide was added. The mixture was brought to $2.5 \mathrm{~mL}$ with distilled water and mixed well. The absorbance was measured immediately at $510 \mathrm{~nm}$ in a T60 UV-visible spectrophotometer. The concentration of total flavonoids was determined using $(+)$-catechin as standard. The concentration of flavonoids was expressed as milligrams of catechin equivalent $(\mathrm{mgCE}) / \mathrm{g}$ of extract.

\section{Determination of total tannin content}

Total tannin content was determined using the FolinCiocalteu reagent as described previously (Ahmed et al. 2018). Briefly, $0.1 \mathrm{~mL}$ of the sample extract is added with $7.5 \mathrm{~mL}$ of distilled water. Then, $0.5 \mathrm{~mL}$ of FolinCiocalteu reagent and $1 \mathrm{~mL}$ of $35 \%$ sodium carbonate solution were added. The total volume was adjusted to $10 \mathrm{~mL}$ by adding distilled water. The mixture was incubated at room temperature for $30 \mathrm{~min}$, and the absorbance was measured at $725 \mathrm{~nm}$ in a T60 UV-visible spectrophotometer. Blank was prepared with water instead of the sample. A set of standard solutions of tannic acid was read against a blank. The concentration of total tannin was determined using tannic acid as standard. The concentration of tannin was expressed as milligrams of tannic acid equivalent (mg TAE)/g of extract.

\section{DPPH free radical scavenging activity}

DPPH (2,2-diphenyl-1-picrylhydrazyl) free radical scavenging activity was carried out using the method described previously (Kabir et al. 2016). Different concentrations $(800,400,200,100,50 \mu \mathrm{g} / \mathrm{mL})$ of extract were dissolved in methanol. Three milliliters of a $0.004 \%$ DPPH solution was added to each test tube. The mixture was incubated for $30 \mathrm{~min}$ in dark condition. The absorbance was measured at $517 \mathrm{~nm}$ in a T60 UV-visible spectrophotometer. The percent inhibition activity was calculated from $\left[\left(A_{\mathrm{C}}-A_{\mathrm{S}}\right) / A_{\mathrm{C}}\right] \times 100$, where $A_{\mathrm{C}}$ is the absorbance of the control and $A_{\mathrm{S}}$ is the absorbance of the sample.

\section{Antibacterial assay}

In vitro antibacterial assay was performed by using the disc diffusion method. Pure cultures of bacteria isolated from clinical specimen were obtained from the Department of Microbiology, Jahangirnagar University. The organisms were Gram-negative Escherichia coli and Gram-positive Bacillus subtilis. The pure culture contains the test organisms on solid media. They were transferred to the sterile nutrient broth and incubated for $18 \mathrm{~h}$ at $37^{\circ} \mathrm{C}$ in an incubator (HYSC, Korea). The optical density of the culture was determined using a T60 UV-visible spectrophotometer at $600 \mathrm{~nm}$. An inoculating loop was used to aseptically transfer the bacterial strains into $5 \mathrm{~mL}$ of media, which was used as a starter culture. The Whatman No. 1 filter paper was used for the preparation of discs which were $5 \mathrm{~mm}$ in diameter. The disks were impregnated with different concentrations $(10 \mathrm{mg} /$ $\mathrm{mL}, 7.5 \mathrm{mg} / \mathrm{mL}, 5 \mathrm{mg} / \mathrm{mL}$, and $2.5 \mathrm{mg} / \mathrm{mL}$ ) of extracts. Each piece of the disc was impregnated with $50 \mu \mathrm{L}$ of extract. So the final concentrations of extracts on the discs were $500,375,250$, and $125 \mu \mathrm{g} / \mathrm{disc}$. The prepared working discs were completely air-dried inside of the class II biological safety cabinet (ESCO, Singapore) and placed on the nutrient agar medium plate. The nutrient agar medium plate was spread with $100 \mu \mathrm{L}$ of starter bacterial culture before the placement of the disks. The culture plates were incubated at $37^{\circ} \mathrm{C}$ in an incubator (HYSC, Korea). After incubation, they were examined for the inhibition of growth. The growth inhibition was measured in terms of zones of inhibition. Zones of inhibition were measured in millimeter-scale using a digital slide caliper. Oxoid $^{\mathrm{TM}}$ Streptomycin antimicrobial susceptibility discs $(25 \mu \mathrm{g})$ (ThermoFisher Scientific, USA) were used as positive control, and sterile distilled water was used as the negative control.

\section{Statistical analysis}

Significant differences among mean values were compared by Tukey's honestly significant difference (HSD) test at a level of significance of $P<0.05$. All data were displayed as the mean \pm standard error of the mean (SEM) at least three independent biological replications. The statistical analysis was performed using Statistical Package for Social Science software (SPSS, version 16.0, IBM Corporation, NY).

\section{Results \\ Qualitative screening of phytochemicals}

Phytochemicals are active chemical compounds produced by plants and involved in several functions. The qualitative phytochemical analysis gave an overview of what secondary metabolites or bioactive components are present in the extracts. Preliminary phytochemical screening was conducted for nine different chemical compounds. Table 1 summarizes the results of the preliminary phytochemical screening. These data showed that the extracts were rich in all the phytochemicals tested. All three of the extracts obtained from seeds indicated that nine different phytochemicals were present in 
Table 1 Preliminary phytochemical screening of different extracts of B. orellana

\begin{tabular}{|c|c|c|c|c|c|c|c|c|c|}
\hline Compounds & $\begin{array}{l}\text { Aqueous } \\
\text { extract } \\
\text { (seed) }\end{array}$ & $\begin{array}{l}\text { Ethanolic } \\
\text { extract } \\
\text { (seed) }\end{array}$ & $\begin{array}{l}\text { Methanolic } \\
\text { extract } \\
\text { (seed) }\end{array}$ & $\begin{array}{l}\text { Aqueous } \\
\text { extract } \\
\text { (branch) }\end{array}$ & $\begin{array}{l}\text { Ethanolic } \\
\text { extract } \\
\text { (branch) }\end{array}$ & $\begin{array}{l}\text { Methanolic } \\
\text { extract } \\
\text { (branch) }\end{array}$ & $\begin{array}{l}\text { Aqueous } \\
\text { extract } \\
\text { (leaf) }\end{array}$ & $\begin{array}{l}\text { Ethanolic } \\
\text { extract } \\
\text { (leaf) }\end{array}$ & $\begin{array}{l}\text { Methanolic } \\
\text { extract } \\
\text { (leaf) }\end{array}$ \\
\hline Carbohydrates & ++ & ++ & ++ & - & - & ++ & + & - & - \\
\hline Alkaloids & ++ & ++ & ++ & + & + & - & - & + & ++ \\
\hline Glycosides & ++ & ++ & ++ & + & - & + & - & + & + \\
\hline Coumarins & + & ++ & ++ & + & ++ & ++ & - & + & + \\
\hline Tannins & + & ++ & ++ & + & +++ & +++ & +++ & +++ & +++ \\
\hline Phenols & + & ++ & +++ & + & +++ & +++ & +++ & +++ & +++ \\
\hline Flavonoids & ++ & ++ & ++ & ++ & ++ & ++ & ++ & ++ & ++ \\
\hline Saponins & +++ & +++ & ++ & - & - & +++ & +++ & + & +++ \\
\hline Proteins & ++ & ++ & +++ & ++ & ++ & ++ & ++ & ++ & ++ \\
\hline
\end{tabular}

Indication: $+++=$ high $;++=$ moderate $+=$ low $;-=$ not detected

the samples. Extracts from branch cuttings showed some negative results which indicated some phytochemicals were not detected in particular extract. Such as carbohydrates were not detected in aqueous and ethanolic extracts of the branch, glycosides were not detected in ethanolic extracts of the branch; saponins were not detected in aqueous and ethanolic extracts of the branch. Ethanolic and methanolic extracts of branch showed the very good presence of tannins and phenols. For the leaf, in aqueous extract, the presence of alkaloids, glycosides, and coumarins was not detected. All three extracts of leaf were rich in tannins and phenols, contained proteins in a moderate amount, and carbohydrates were detected in a lower amount.

\section{Quantitative determination of phytochemicals Determination of total phenolic content}

Total phenolic content in different extracts obtained from seed, branch, and leaf of $B$. orellana is shown in
Fig. 1. The highest $(186.02 \mathrm{mg} / \mathrm{g}$ of extract) phenolic content was found in the methanolic extract of leaf, and the lowest $(46.34 \mathrm{mg} / \mathrm{g}$ of extract) phenolic content was found in ethanolic extract of seed.

\section{Determination of total flavonoid content}

Figure 2 represents the total flavonoid content in different extracts obtained from seed, branch, and leaf of $B$. orellana. The highest $(61.01 \mathrm{mg} / \mathrm{g}$ of extract) flavonoid content was found in aqueous extract of leaf, and the lowest $(6.84 \mathrm{mg} / \mathrm{g}$ of extract) flavonoid content was found in methanolic extract of seed.

\section{Determination of total tannin content}

Total tannin content in different extracts obtained from seed, branch, and leaf of B. orellana is shown in Fig. 3. The highest $(36.74 \mathrm{mg} / \mathrm{g}$ of extract) tannin content was found in aqueous extract of leaf, and the lowest (5.86

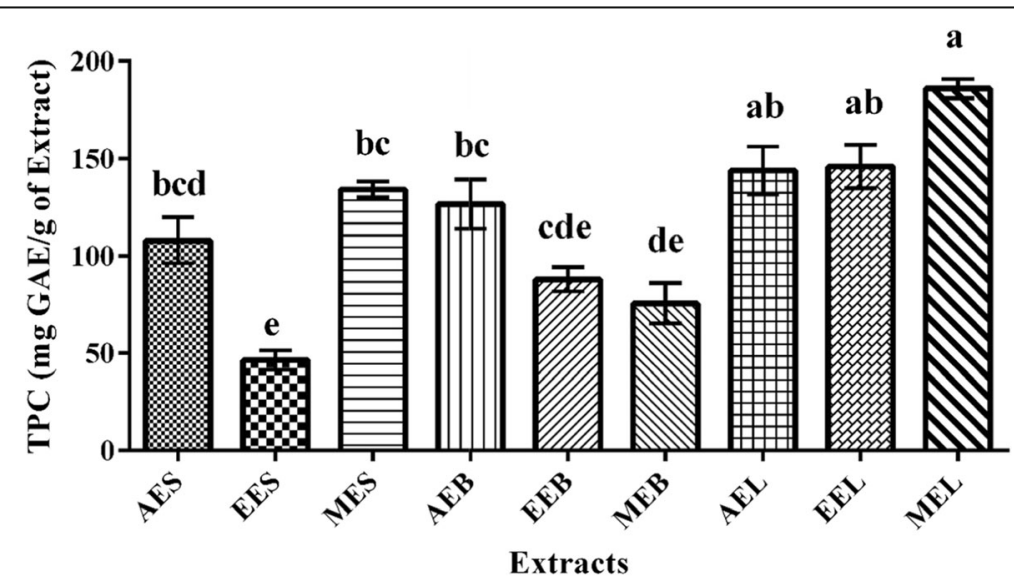

Fig. 1 Total phenolic content expressed as mg GAE (gallic acid equivalent)/g of extract in different extracts of $B$. orellana. Bars with different letters are significantly different according to Tukey's HSD tests $(P<0.05)$. TPC = total phenolic content; $A E S=$ aqueous extract $($ seed); $E$ ES $=$ ethanolic extract (seed); $M E S$ = methanolic extract (seed); $A E B$ = aqueous extract (branch); EEB = ethanolic extract (branch); $M E B=$ methanolic extract (branch); $\mathrm{AEL}=$ aqueous extract (leaf); EEL = ethanolic extract (Leaf); MEL = methanolic extract (leaf) 


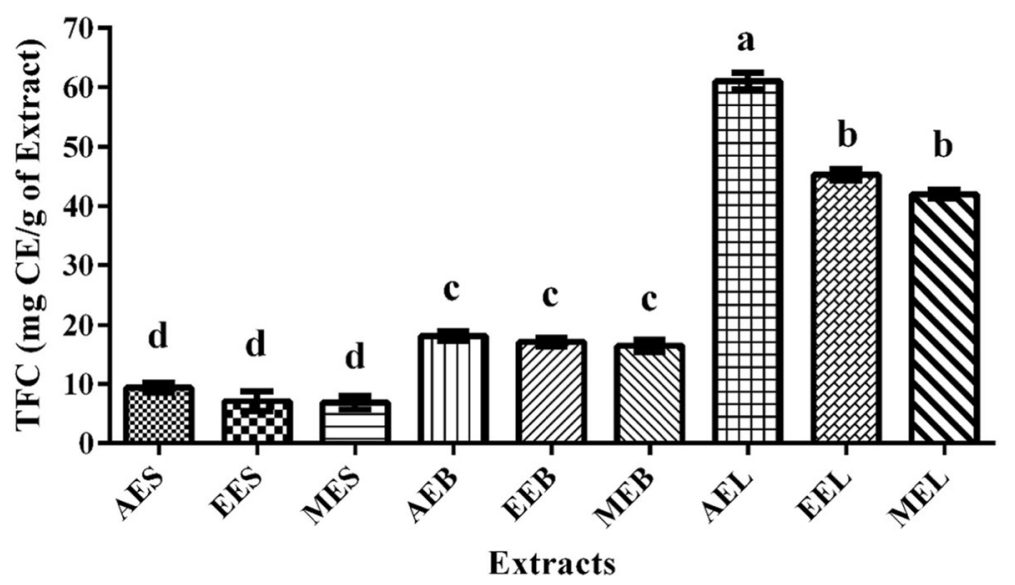

Fig. 2 Total flavonoid content expressed as mg CE (catechin equivalent)/g of extract in different extracts of B. orellana. Bars with different letters are significantly different according to Tukey's HSD tests $(P<0.05)$. TFC $=$ total flavonoid content; AES = aqueous extract (seed); EES $=$ ethanolic extract (seed); $M E S$ = methanolic extract (seed); $A E B=$ aqueous extract (branch); EEB = ethanolic extract (branch); $M E B=$ methanolic extract (branch); $A E L=$ aqueous extract (leaf); $E E L=$ ethanolic extract (leaf); MEL = methanolic extract (leaf)

$\mathrm{mg} / \mathrm{g}$ of extract) tannin content was found in methanolic extract of the branch.

\section{$D P P H$ radical scavenging activity}

DPPH radical scavenging activity was used to evaluate the antioxidant potential of different extracts from B. orellana. Figure 4 showed the comparative antioxidant activity in terms of DPPH radical scavenging assay where the antioxidant potentials were expressed as \% DPPH scavenged. From the assay, it was clearly evident that the extracts obtained from leaf were best for DPPH scavenging. The highest activity was found for aqueous extract of the leaf at $800 \mu \mathrm{g} / \mathrm{mL}$ extract concentration, which showed $93.62 \%$ scavenging activity followed by ethanolic extract of the leaf (92.47\%) and methanolic extract of the leaf $(91.72 \%)$ at $800 \mu \mathrm{g} / \mathrm{mL}$ extract concentration. For the extracts obtained from the branch, it was seen that ethanolic extract (88.9\%) and methanolic extract $(80.37 \%)$ had better scavenging potential at $800 \mu \mathrm{g} / \mathrm{mL}$ extract concentration than the aqueous extract (68.76\%). And the extracts obtained from seed had lower antioxidant capacity where we have found 53.05, 49.28, and 42.60\% DPPH scavenging activity at $800 \mu \mathrm{g} / \mathrm{mL}$ extract concentration of methanolic, ethanolic, and aqueous extract respectively.

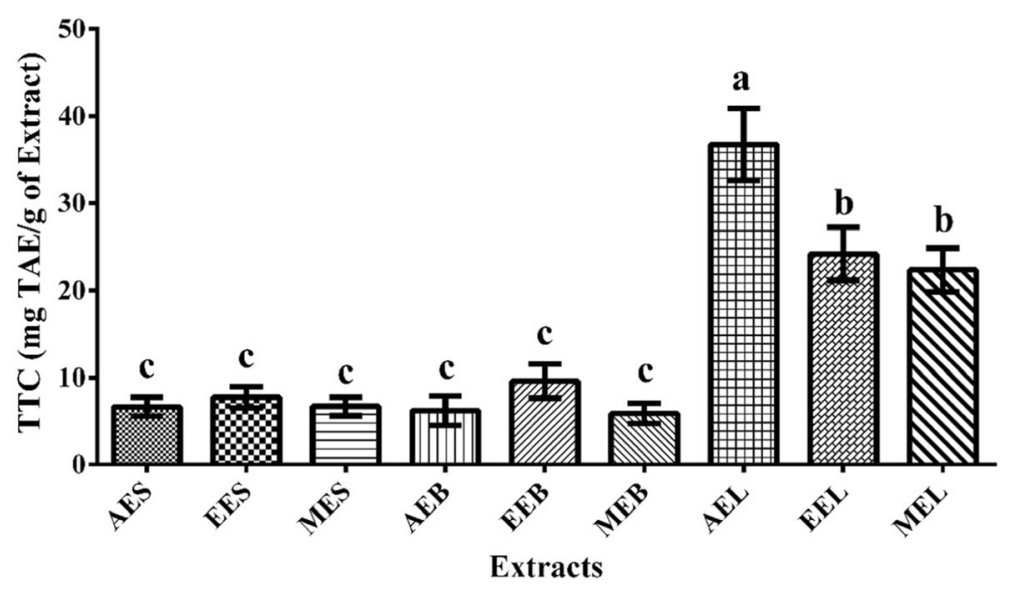

Fig. 3 Total tannin content expressed as mg TAE (tannic acid equivalent)/g of extract in different extracts of $B$. orellana. Bars with different letters are significantly different according to Tukey's HSD tests $(P<0.05)$. TTC = total tannin content; AES = aqueous extract (seed); EES = ethanolic extract (seed); MES = methanolic extract (seed); $\mathrm{AEB}=$ aqueous extract (branch); $\mathrm{EEB}=$ ethanolic extract (branch); $M E B=$ methanolic extract (branch); $\mathrm{AEL}=$ aqueous extract (leaf); $\mathrm{EEL}=$ ethanolic extract (leaf); $\mathrm{MEL}=$ methanolic extract (leaf) 


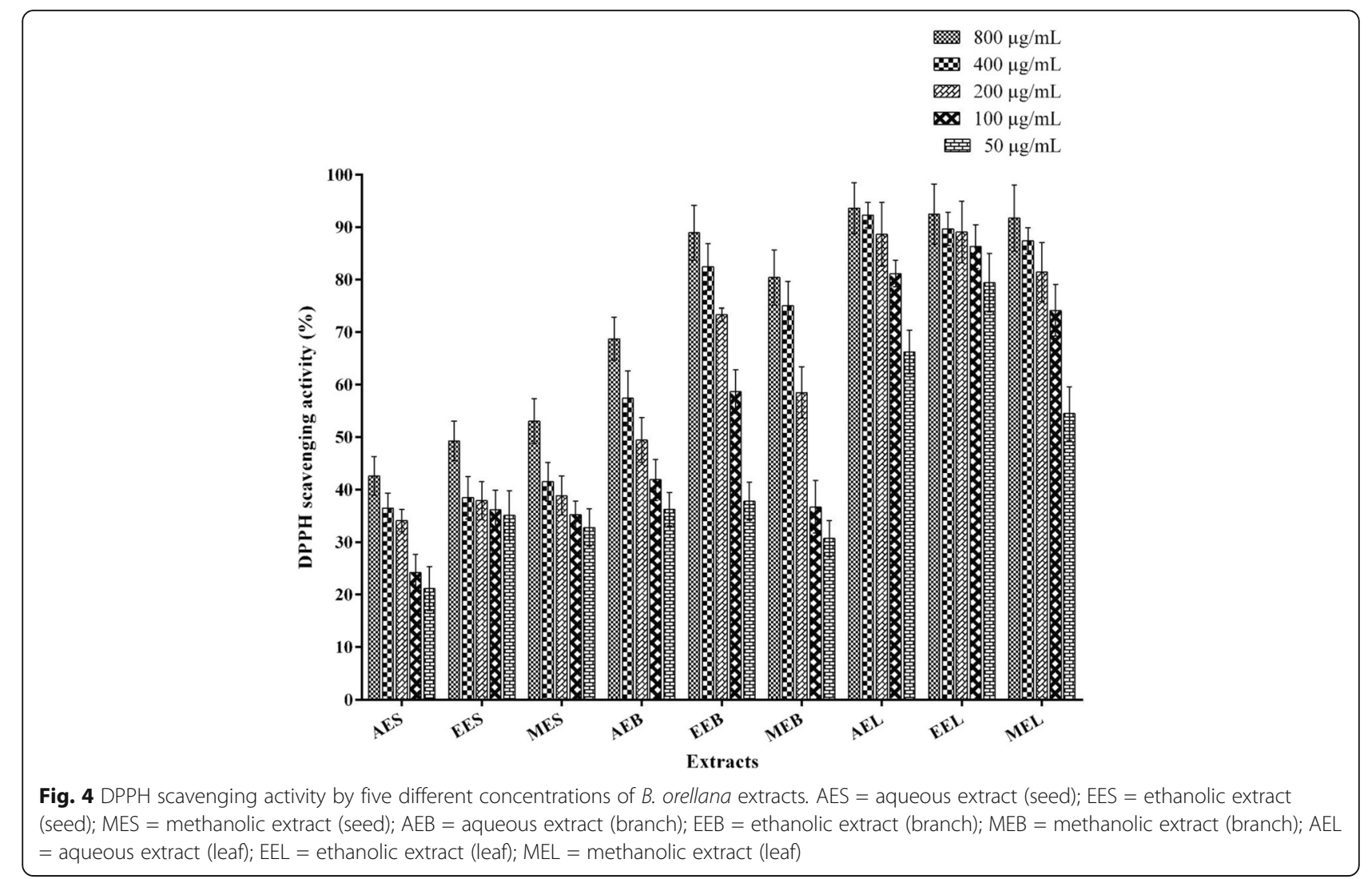

\section{Antibacterial activity}

Antibacterial activity was performed for both Gramnegative (Escherichia coli) and Gram-positive (Bacillus subtilis) bacteria. Tables 2 and 3 accommodate the zone of inhibition observed for Gram-negative bacteria $E$. coli and Gram-positive bacteria B. subtilis by different concentrations of extracts, respectively. Inhibition of bacterial growth was observed for both the bacterial species by all of the extracts. For Gram-negative bacteria E. coli, the highest zone of inhibition $(13.1 \mathrm{~mm})$ was found for aqueous extract of leaf and the lowest zone of inhibition
$(6.1 \mathrm{~mm})$ was found for the methanolic extract of the branch at $10 \mathrm{mg} / \mathrm{mL}$ extract concentration.

For Gram-positive bacteria B. subtilis, the highest zone of inhibition $(15.7 \mathrm{~mm})$ was found for the methanolic extract of leaf and the lowest zone of inhibition $(7.9 \mathrm{~mm})$ was found for the methanolic extract of seed at $10 \mathrm{mg} /$ $\mathrm{mL}$ extract concentration.

\section{Discussion}

The presence of a wide range of phytochemical constituents including carbohydrate, alkaloid, glycosides,

Table 2 Zone of inhibition observed for Gram-negative bacteria Escherichia coli by different concentrations of extracts

\begin{tabular}{|c|c|c|c|c|}
\hline \multirow[t]{2}{*}{ Samples } & \multicolumn{4}{|c|}{ Zone of inhibition $(\mathrm{mm})$} \\
\hline & $10 \mathrm{mg} / \mathrm{mL}$ & $7.5 \mathrm{mg} / \mathrm{mL}$ & $5 \mathrm{mg} / \mathrm{mL}$ & $2.5 \mathrm{mg} / \mathrm{mL}$ \\
\hline Aqueous extract (seed) & $9.1 \pm 0.3$ & $8.5 \pm 0.3$ & $8.1 \pm 0.3$ & $7.6 \pm 0.3$ \\
\hline Ethanolic extract (seed) & $8.5 \pm 0.3$ & $8.3 \pm 0.2$ & $8.1 \pm 0.2$ & $7.8 \pm 0.2$ \\
\hline Methanolic extract (seed) & $6.9 \pm 0.2$ & $6.7 \pm 0.2$ & $5.9 \pm 0.2$ & $5.4 \pm 0.2$ \\
\hline Aqueous extract (branch) & $10.2 \pm 0.3$ & $8.9 \pm 0.2$ & $8.5 \pm 0.3$ & $7.2 \pm 0.2$ \\
\hline Ethanolic extract (branch) & $9.2 \pm 0.2$ & $8.8 \pm 0.2$ & $7.6 \pm 0.2$ & $7.1 \pm 0.3$ \\
\hline Methanolic extract (branch) & $6.1 \pm 0.2$ & $5.7 \pm 0.2$ & 0 & 0 \\
\hline Aqueous extract (leaf) & $13.1 \pm 0.3$ & $9.0 \pm 0.3$ & $8.2 \pm 0.3$ & $7.4 \pm 0.3$ \\
\hline Ethanolic extract (leaf) & $12.6 \pm 0.3$ & $9.2 \pm 0.2$ & $8.0 \pm 0.2$ & $7.1 \pm 0.4$ \\
\hline Methanolic extract (leaf) & $12.9 \pm 0.2$ & $8.4 \pm 0.3$ & $7.8 \pm 0.2$ & $7.2 \pm 0.2$ \\
\hline
\end{tabular}


Table 3 Zone of inhibition observed for Gram-positive bacteria Bacillus subtilis by different concentrations of extracts

\begin{tabular}{|c|c|c|c|c|}
\hline \multirow[t]{2}{*}{ Samples } & \multicolumn{4}{|c|}{ Zone of inhibition (mm) } \\
\hline & $10 \mathrm{mg} / \mathrm{mL}$ & $7.5 \mathrm{mg} / \mathrm{mL}$ & $5 \mathrm{mg} / \mathrm{mL}$ & $2.5 \mathrm{mg} / \mathrm{mL}$ \\
\hline Aqueous extract (seed) & $10.1 \pm 0.2$ & $9.3 \pm 0.3$ & $8.2 \pm 0.2$ & $8.0 \pm 0.2$ \\
\hline Ethanolic extract (seed) & $13.0 \pm 0.2$ & $11.3 \pm 0.2$ & $10.0 \pm 0.3$ & $8.2 \pm 0.2$ \\
\hline Methanolic extract (seed) & $7.9 \pm 0.2$ & $7.5 \pm 0.2$ & $7.3 \pm 0.3$ & $7.1 \pm 0.2$ \\
\hline Aqueous extract (branch) & $8.6 \pm 0.3$ & $8.1 \pm 0.3$ & $7.8 \pm 0.2$ & $6.5 \pm 0.2$ \\
\hline Ethanolic extract (branch) & $10.9 \pm 0.2$ & $9.5 \pm 0.2$ & $8.3 \pm 0.3$ & $7.4 \pm 0.3$ \\
\hline Methanolic extract (branch) & $9.8 \pm 0.3$ & $8.8 \pm 0.3$ & $8.4 \pm 0.2$ & $7.1 \pm 0.2$ \\
\hline Aqueous extract (leaf) & $12.4 \pm 0.2$ & $9.3 \pm 0.2$ & $8.7 \pm 0.2$ & $8.0 \pm 0.3$ \\
\hline Ethanolic extract (leaf) & $12.9 \pm 0.3$ & $9.6 \pm 0.2$ & $8.5 \pm 0.4$ & $7.3 \pm 0.2$ \\
\hline Methanolic extract (leaf) & $15.7 \pm 0.2$ & $10.8 \pm 0.3$ & $8.0 \pm 0.3$ & $7.0 \pm 0.2$ \\
\hline
\end{tabular}

coumarin, tannin, phenol, flavonoids, saponin, and protein provides some evidence in support of the various ethnopharmacological use. Till now, phytochemical investigations have revealed the presence of almost twenty-five types of chemical compounds from $B$. orellana (Giorgi et al. 2013). Our study successfully revealed the presence of nine different phytochemicals in different extracts. The presence and absence of phytochemicals were dependent on the type of plant parts as well as different solvents.

Phenolic compounds have an aromatic ring, which can bear one or more substituents. They are distributed in a wide range of plants and play an important role in producing color, odor, and defense substances against pathogens. Phenolic compounds have been widely explored in a good number of studies because they have various pharmacological activities (Huang et al. 2009; ZarzaGarcía et al. 2017). Our study showed that leaf extracts of different solvents were rich in phenolic compounds. Phenolics are prevalent in leaves as evident by our study and also supported by previous studies. The present study also showed that the seed and branch samples contain a considerable quantity of phenolic compounds. A study performed in Colombia by Viuda-Martos et al. (2012) utilized ethanolic extract of leaf and seed to quantify the phenolics and flavonoids and reported total phenol content as $1.81 \mathrm{mg} / \mathrm{g}$ for ethanolic leaf extract and $0.74 \mathrm{mg} / \mathrm{g}$ for ethanolic seed extract (Viuda-Martos et al. 2012). The study by Zarza-García et al. (2017) conducted a study in Mexico by utilizing three Mayan accessions of $B$. orellana leaves where they found total phenolic content as 113.53, 158.77, and $163.00 \mathrm{mg} / \mathrm{g}$ in three accessions respectively (Zarza-García et al. 2017). The result of our study suggested the phenolic compounds present in $B$. orellana leaf are more soluble in methanol than the ethanol and water.

Flavonoids resemble a class of naturally occurring phenolic compounds in plants, which constitute more than 4000 compounds (Ren et al. 2003). They have been shown to exert a variety of biological activities. Traditional folk medicine utilizes flavonoids as an active constituent and has been used by physicians to manage various diseases and disorders (Havsteen 1983). In our study, the total flavonoid content is considerably higher in extracts obtained from the leaf. The study by ViudaMartos et al. (2012) found similar result where the total flavonoid content was found as $65.53 \mathrm{mg} / \mathrm{g}$ for ethanolic leaf extract and $22.18 \mathrm{mg} / \mathrm{g}$ for ethanolic seed extract (Viuda-Martos et al. 2012).

Tannins are natural, water-soluble, polyphenolic compounds with a molecular weight ranging from 500 to 3000 Da (Dalton). Different plant species were shown to contain tannins that have specific physical and chemical properties as well as outstanding pharmacological significance (Chung et al. 1998). In our study, as the other two phytochemicals quantified, leaf extracts are also rich in tannins than the branch or seed. Karmakar et al. (2018) quantify tannins in the ethanolic extract of seeds of $B$. orellana, where total tannin content was $25 \mathrm{mg} / \mathrm{g}$ of dry extract (Karmakar et al. 2018). Both the flavonoid and tannin are prevalent in the aqueous extract which suggested that the flavonoid and tannin present in $B$. orellana leaf are more soluble in water than the ethanol and methanol.

Plants contain different antioxidants naturally which are responsible for inhibiting the harmful effects of oxidative stress. The antioxidant activities are attributed to the presence of active phytoconstituents, including phenolics, flavonoids, and related compounds (Subramanian et al. 2013). In our study, the free radical scavenging activity was evaluated by the DPPH (2,2-diphenyl-1-picrylhydrazyl) method, which is regarded as an easy, reliable, sensitive, and rapid method, and almost $90 \%$ of antioxidant studies are conducted with this method (Moon and Shibamoto 2009). Shilpi et al. (2006) found that $500 \mu \mathrm{g} /$ $\mathrm{mL}$ concentration of leaf extract exhibited 90.58\% DPPH scavenging activity, whereas Karmakar et al. (2018) utilized ethanolic extract of seeds and found $75.77 \% \mathrm{DPPH}$ 
scavenging activity at $512 \mu \mathrm{g} / \mathrm{mL}$ concentration. ViudaMartos et al. (2012) reported $94.20 \%$ and $93.01 \%$ DPPH scavenging activity for ethanolic leaf and seed extracts respectively.

In the antibacterial assay, higher activity was found by extracts obtained from leaf than the extracts from seed and branch. In the case of leaf extracts, activity was higher against Gram-positive bacteria than Gramnegative bacteria. However, the extracts obtained from seeds and stems were also effective to some extent against the bacteria, which suggested their utility as antibacterial agent. The difference in cell wall structure between Gram-positive and Gram-negative bacteria is a contributing factor to the susceptibility of bacteria to phytochemicals. In Gram-negative bacteria, the cell wall is more complex due to the presence of a lipopolysaccharide layer outside the peptidoglycan layer. That is why the layer may turn out to be impermeable to many substances, whereas gram-positive bacteria have only the peptidoglycan layer. That is why the permeability is higher for some substances. In light of this explanation, we can say that the phytochemicals present are more active against the Gram-positive bacteria because they have better permeability to penetrate into the cell structure. The previous study by Abayomi et al. demonstrated the positive bactericidal activities of $B$. orellana seed extracts against Gram-positive bacteria Staphylococcus aureus and Bacillus subtilis. However, they did not find any activity against Gram-negative bacteria such as Escherichia coli (Abayomi et al. 2014). The study performed by Irobi et al. (1996) indicated significant antimicrobial activity by $B$. orellana leaf extracts against standard strains of Gram-positive bacteria including B. subtilis, Streptococcus faecalis, and S. aureus. However, their study found slight inhibition for the Gram-negative bacteria (Irobi et al. 1996). Fleischer et al. (2003) utilized ethanolic extract of leaf and seed to study the antibacterial activity of $B$. orellana where they found activity against all the Gram-positive and Gram-negative bacteria (Fleischer et al. 2003). A Bangladeshi study performed by Alim et al. (2016) showed the antibacterial activity of methanolic extract of $B$. orellana leaf where the higher zone of inhibition was found for Gram-negative bacteria (E. coli) than the Gram-positive bacteria (B. subtilis) (Alim et al. 2016). Another Bangladeshi study by Shilpi et al. (2006) showed that methanolic extract of the leaf has inhibitory activity against Gram-negative bacteria (E. coli) (Shilpi et al. 2006). Karmakar et al. (2018) utilized ethanolic extract of seeds where they found antibacterial activity against Gram-negative bacteria (E. coli) (Karmakar et al. 2018). The study by Shilpi et al. (2006) and Karmakar et al. (2018) did not use B. subtilis in their experiment.

\section{Conclusion}

From the present study, it is quite clear that among the three different plant parts tested, the leaves are most useful in every aspect as they are rich in phytochemicals and antioxidants as well as they showed the best antibacterial activity. However, the solvents used in this study did not let us get a concise conclusion for which solvent is best because they showed a different pattern in different experiments. But we can say that aqueous extract is more effective followed by methanolic and ethanolic extracts. It is quite clear from the study that the concentration and type of bioactive substances present in the extracts depended on several factors which may be attributed to the season, geography and environment, soil type and climate, processing methods such as type of solvent, etc. The present study has updated the state of knowledge about $B$. orellana to some extent by bringing together the existing literature information and novelties such as comparative phytochemical profiles, antioxidant activities, and antibacterial potentials. Moreover, comparative insights into phytochemical profiles may help to reveal the type and nature of chemical diversity in this useful plant. It is also worth mentioning that the study was performed from the perspective of Bangladesh, where there is a report of the plant is at risk of being lost in all or part of their distribution ranges because of reduction in their population numbers due to habitat destruction and over-collecting. The study may be very preliminary in nature, but it is the foundation for future investigation. A more detailed investigation is required to explore the in-depth medicinal properties as well as their mechanism of action.

\section{Abbreviations}

DPPH: 2,2-Diphenyl-1-picrylhydrazyl; GAE: Gallic acid equivalent; CE: Catechin equivalent; TAE: Tannic acid equivalent; TPC: Total phenolic content;

TFC: Total flavonoid content; TTC: Total tannin content; AES: Aqueous extract (seed); EES: Ethanolic extract (seed); MES: Methanolic extract (seed);

AEB: Aqueous extract (branch); EEB: Ethanolic extract (branch); MEB: Methanolic extract (branch); AEL: Aqueous extract (leaf); EEL: Ethanolic extract (leaf); MEL: Methanolic extract (leaf); SEM: Standard error of the mean; SD: Standard deviation

\footnotetext{
Acknowledgements

The authors greatly acknowledge Dr. Isidore Gomes for generously providing the seeds of Doigota (B. orellana) from the cultivated plants in his personal garden located at Hemayetpur, Savar, Dhaka, Bangladesh. Also, the authors are thankful to all the lab members who provided their knowledgeful insights in every step of this research work.
}

\section{Authors' contributions}

Abdullah Mohammad Shohael generated the idea and designed the experiments. Sium Ahmed, Bilkis Mehrin Moni, and Shawon Ahmed collected and prepared the samples and performed all the experiments. Sium Ahmed, Bilkis Mehrin Moni, and Shawon Ahmed analyzed the data. Sium Ahmed wrote the manuscript. Bilkis Mehrin Moni, Donald James Gomes, and Abdullah Mohammad Shohael reviewed the manuscript. The authors read and approved the final manuscript. 


\section{Funding}

This research was partially supported by the research grant provided by GARE (Grant for Advance Research in Education LS2016165 no. 37.20.0000.004.033.020.2016.7725) funded by the Ministry of Education, Bangladesh, and Special Allocation in Science and Technology of Ministry of Science and Technology (no. 39.00.0000.09.06.79.2017/ES-99), Bangladesh.

\section{Availability of data and materials}

All data generated during this study are included in this published article.

\section{Ethics approval and consent to participate}

Not applicable.

\section{Consent for publication}

Not applicable.

\section{Competing interests}

The authors declare that they have no competing interests.

\section{Author details}

${ }^{1}$ Cell Genetics and Plant Biotechnology Laboratory, Department of Biotechnology and Genetic Engineering, Jahangirnagar University, Savar, Dhaka 1342, Bangladesh. ${ }^{2}$ Department of Microbiology, Faculty of Biological Sciences, University of Dhaka, Dhaka 1000, Bangladesh.

Received: 1 January 2020 Accepted: 3 June 2020

\section{Published online: 15 June 2020}

\section{References}

Abayomi M, Adebayo AS, Bennett D, Porter R, Shelly-Campbell J (2014) In vitro antioxidant activity of Bixa orellana (Annatto) seed extract. J Appl Pharm Sci 4(2):101-106

Ahmed S, Bin RF, Ahmed S, Mohammad Shohael A (2018) Insights into the bioactive compounds, antioxidant potential and TLC profiling of different extracts of Tomato plants. Jahangirnagar Univ J Biol Sci 7(2):65-77

Alim S, Bairagi N, Shahriyar S, Kabir M (2016) Against some pathogenic bacteria and comparative investigation on some standard antibiotics. 5(2):178-181

Chung K-T, Wong TY, Wei C-I, Huang Y-W, Lin Y (1998) Tannins and human health: a review. Crit Rev Food Sci Nutr 38(6):421-464. https://doi.org/10. 1080/10408699891274273

Fleischer TC, Ameade EPK, Mensah MLK, Sawer IK (2003) Antimicrobial activity of the leaves and seeds of Bixa orellana. Fitoterapia. 74(1-2):136-138

Giorgi A, De Marinis P, Granelli G, Chiesa LM, Panseri S (2013) Secondary metabolite profile, antioxidant capacity, and mosquito repellent activity of Bixa orellana from Brazilian Amazon region. J Chemother 2013

Havsteen B (1983) Flavonoids, a class of natural products of high pharmacological potency. Biochem Pharmacol Elsevier 32(7):1141-1148

Huang W-Y, Cai Y-Z, Zhang Y (2009) Natural phenolic compounds from medicinal herbs and dietary plants: potential use for cancer prevention. Nutr Cancer 62(1):1-20

Irobi ON, Moo-Young M, Anderson WA (1996) Antimicrobial activity of annatto (Bixa orellana) extract. Int J Pharmacogn 34(2):87-90

Kabir H, Shah M, Hossain MM, Kabir M, Rahman M, Hasanat A et al (2016) Phytochemical screening, antioxidant, thrombolytic, a-amylase inhibition and cytotoxic activities of ethanol extract of Steudnera colocasiifolia K. Koch leaves. J Young Pharm 8(4)

Karmakar U, Sultana S, Nishi S, Biswas NN, Hossain L, Sheikh S (2018) Antioxidant, analgesic, antimicrobial, and anthelmintic activity of the dried seeds of Bixa orellana (L). Int J Pharm 8:150-163

Ksouri R, Falleh H, Megdiche W, Trabelsi N, Mhamdi B, Chaieb K et al (2009) Antioxidant and antimicrobial activities of the edible medicinal halophyte Tamarix gallica L. and related polyphenolic constituents. Food Chem Toxicol 47(8):2083-2091

Kumar A, llavarasan R, Jayachandran T, Decaraman M, Aravindhan P, Padmanabhan N et al (2009) Phytochemicals investigation on a tropical plant, Syzygium cumini from Kattuppalayam, Erode district, Tamil Nadu, South India. Pak J Nutr 8(1):83-85

Mello AAA, Lima LCF (1990) Situation of culture in Brazil annatto and perspectives. Cult. annatto Brazil. Bahia State Univ, Southwest Bahia, pp 88-90

Moon J-K, Shibamoto T (2009) Antioxidant assays for plant and food components. J Agric Food Chem 57(5):1655-1666
Patani M, Patel M, Sarwa K, Bhadari A (2013) Research and reviews: journal of microbiology and biotechnology isolation and antimicrobial evaluation of Bixa orellana and Linum usitatissimum. 2(2):4-10

Peash TA, Sheikh B, Rahman M, Shohael AM (2017) Thin layer chromatographic profiling and phytochemical screening of six medicinal plants in Bangladesh. Int J Biosci 11(1):131-140

Rahman MM, Fakir MSA (2015) Biodiversity of medicinal plants in Bangladesh: prospects and problems of conservation and utilization. Int J Minor Fruits, Med Aromat Plants 1(1):1-9

Ren W, Qiao Z, Wang H, Zhu L, Zhang L (2003) Flavonoids: promising anticancer agents. Med Res Rev 23(4):519-534

Rincón CT, Montoya JE, Gómez GL (2014) Optimizing the extraction of phenolic compounds from Bixa orellana $\mathrm{L}$. and effect of physicochemical conditions on its antioxidant activity. J Med Plant Res 8(46):1333-1339

Rizk AM (1982) Constituents of plants growing in Quatar. 1. A chemical survey of sixty plants. Fitoterapia. 53:35-44

Shilpi JA, Taufiq-Ur-Rahman M, Uddin SJ, Alam MS, Sadhu SK, Seidel V (2006) Preliminary pharmacological screening of Bixa orellana L. leaves. J Ethnopharmacol 108(2):264-271

Shohael AM, Ali MB, Yu KW, Hahn EJ, Islam R, Paek KY (2006b) Effect of light on oxidative stress, secondary metabolites and induction of antioxidant enzymes in Eleutherococcus senticosus somatic embryos in bioreactor. Process Biochem 41(5):1179-1185

Shohael AM, Ali MB, Yu KW, Hahn E-J, Paek KY (2006a) Effect of temperature on secondary metabolites production and antioxidant enzyme activities in Eleutherococcus senticosus somatic embryos. Plant Cell Tissue Organ Cult 85(2):219-228

Smith J (2006) Annatto extracts-chemical and technical assessment. Chem Tech Assess Man:1-21

Soloway S, Wilen SH (1952) Improved ferric chloride test for phenols. Anal Chem

Stohs SJ (2014) Safety and efficacy of Bixa orellana (achiote, annatto) leaf extracts. Phyther Res 28(7):956-960

Subramanian R, Subbramaniyan P, Raj V (2013) Antioxidant activity of the stem bark of Shorea roxburghii and its silver reducing power. SpringerPlus. 2(1):28

Tamil Selvi A, Dinesh MG, Satyan RS, Chandrasekaran B, Rose C (2011) Leaf and seed extracts of Bixa orellana $\mathrm{L}$. exert anti-microbial activity against bacterial pathogens. J Appl Pharm Sci 1(9):116-120

Tiwari S. Plants: a rich source of herbal medicine. J Nat Prod 2008;1(0):27-35.

Ugochukwu SC, Uche A, Ifeanyi O (2013) Preliminary phytochemical screening of different solvent extracts of stem bark and roots of Dennetia tripetala $\mathrm{G}$. Baker. Asian J Plant Sci Res 3(3):10-13

Viuda-Martos M, Ciro-Gómez GL, Ruiz-Navajas Y, Zapata-Montoya JE, Sendra E, Pérez-Álvarez JA et al (2012) In vitro antioxidant and antibacterial activities of extracts from annatto (Bixa orellana L.) leaves and seeds. J Food Saf 32(4): 399-406

Yadav R, Khare RK, Singhal A (2017) Qualitative phytochemical screening of some selected medicinal plants of shivpuri district (mp). Int J Life Sci Sci Res 3(1): 844-847

Yusuf M, Chowdhury JU, Wahab MA, Begum J (1994) Medicinal plants of Bangladesh. Bangladesh Counc. Sci. Ind. Res, Dhaka, p 192

Zarza-García AL, Sauri-Duch E, Raddatz-Mota D, Cuevas-Glory LF, Pinzón-López LL, Rivera-Cabrera F et al (2017) Pharmacological, phytochemical and morphological study of three Mayan accessions of Bixa orellana L. leaves. Emirates J Food Agric 29(3):163-169

\section{Publisher's Note}

Springer Nature remains neutral with regard to jurisdictional claims in published maps and institutional affiliations. 